University of Arkansas, Fayetteville

ScholarWorks@UARK

$5-2011$

\title{
Effects of piston uplift, piston friction, and machine deflection in reduced triaxial extension testing
}

Morgan Race

University of Arkansas, Fayetteville

Follow this and additional works at: https://scholarworks.uark.edu/cveguht

Part of the Civil Engineering Commons, and the Hydraulic Engineering Commons

\section{Citation}

Race, M. (2011). Effects of piston uplift, piston friction, and machine deflection in reduced triaxial extension testing. Civil Engineering Undergraduate Honors Theses Retrieved from https://scholarworks.uark.edu/cveguht/12 


\title{
Effects of Piston Uplift, Piston Friction, and Machine Deflection in Reduced Triaxial Extension Testing
}

\author{
Morgan L. Race ${ }^{1}$ and Richard A. Coffman ${ }^{2}$
}

${ }^{1}$ Undergraduate Honors Research Assistant, Dept. of Civil Engineering, University of Arkansas, Fayetteville, Arkansas 72701, Email: mrace@uark.edu (Corresponding Author) ${ }^{2}$ Assistant Professor, Dept. of Civil Engineering, University of Arkansas, Fayetteville, Arkansas 72701, Phone: 479-575-8767, Email: rick@uark.edu

\section{ABSTRACT}

A series of Reduced Triaxial Extension (RTE) tests were conducted on dummy (brass) and null (water) samples to determine the effects of (corrections required for) piston uplift, piston friction and system compliance associated with RTE tests. During the consolidation stage of RTE tests, the sample may be consolidated in isotropic or anisotropic stress conditions. During the shearing stage of an RTE test, the sample is unloaded in the axial direction by decreasing the deviator stress while the radial stress remains constant.

Ten (10) tests were conducted on a brass "dummy" sample. The device was assembled in the same manner as for tests conducted on soil samples. The tests simulated the backpressure saturation and consolidation stages of testing. For various effective stresses (cell pressure and backpressure combinations) the load associated with piston uplift and piston friction was measured. Correlations were developed for piston uplift and piston friction.

Eleven (11) tests were on "dummy" ice samples The samples, used as place holders, were set-up in the same manner as for tests conducted on soil samples then allowed to melt before shearing. For various effective stresses the load associated with machine deflection was measured. The contribution of the membrane elongation and filter paper were determined.

\section{INTRODUCTION}

Advances in triaxial testing equipment including automated pumps and automated load frames used for measuring and controlling cell pressure, pore pressure, and axial force have led to ease in conducting these tests. This equipment has enabled triaxial tests to be conducted on samples consolidated under isotropic or anisotropic conditions. Ladd and Degroot (2003) state that, "computer automated stress path triaxial equipment makes the task of achieving $\mathrm{K}_{\mathrm{o}}$ consolidation much simpler and more efficient than manual methods." Ladd (2009) also mentioned the benefits of using Geotechnical Test Acquisition Control (GEOTAC) equipment and software. In fact, the GEOTAC equipment and software are increasing the capabilities of triaxial testing, enabling many users to conduct SHANSEP analyses by following the procedures outlined by Ladd and Foote (1974) and Ladd and DeGroot (2003). Users are permitted to conduct triaxial compression and triaxial extension tests on soft soils to obtain undrained shear strength estimates that approximate the undrained shear strength obtained from direct simple shear tests. However, many users of the equipment may be unaware that the software does not account for change in sample area, piston uplift, piston friction, and filter paper and membrane effects in triaxial 
compression or triaxial extension testing. These effects may be leading to incorrect levels of anisotropic stress being applied to the sample during consolidation, and to incorrect axial force measurements being obtained during shearing. Several researchers have developed ways to correct for change in area, piston uplift, piston friction, and filter paper and membrane effects in triaxial compression, however, there has been limited discussion on how to correct for these effects in triaxial extension testing. The techniques used to account for these effects in triaxial extension testing are presented.

\section{LITERATURE REVIEW}

Several researchers have investigated and discussed the effects of sample necking, piston uplift, piston friction, filter paper and rubber membranes on triaxial extension strength data. Roscoe (1963), Shibata and Karube (1965), Lade and Duncan (1973), Yaramuro and Lade (1995), and Lade et al. (1996) focused on the effects of sample necking and the prevention of sample necking by using cubic samples or membranes with cylindrical plates. These researchers were trying to eliminate the need for the use of area corrections to compensate for strain localization. Mitachi et al. (1988) and Wu and Kolymbas (1991) used internal load cells to isolate the effects of piston friction, and conducted tension tests on pieces of rubber membrane to account for the force carried by the membrane. Mitachi et al. (1988) suggest using Equation 1 to determine the axial force carried by the rubber membrane (assuming there is no slip between the membrane and the specimen and neglecting the form change of the rubber membrane due to necking).

$$
F_{m}=\pi D t E_{m} \varepsilon_{a} \quad \text { Equation } 1
$$

where

$\mathrm{F}_{\mathrm{m}}=$ axial force carried by the rubber membrane,

$\mathrm{D}=$ diameter of sample,

$\mathrm{t}=$ instantaneous thickness of the rubber membrane,

$\mathrm{E}_{\mathrm{m}}=$ tensile modulus of the rubber membrane, and

$\varepsilon_{\mathrm{a}}=$ axial strain.

\section{METHODS AND PROCEDURES}

A series of triaxial extension tests (21 tests) were conducted to determine the contribution of piston uplift, piston friction, membrane elongation and filter paper on measured shear strength. The series of tests consisted of two sets of experiments. The first set of experiments (10 tests) utilized a 1.5 inch $(3.81 \mathrm{~cm})$ diameter by 3.0 inch $(762 \mathrm{~cm})$ tall brass dummy sample while the second set of experiments (11 tests) utilized a 1.5 inch (3.81 $\mathrm{cm}$ ) diameter by 3.0 inch $(762 \mathrm{~cm})$ tall ice dummy sample. Because no American Society for Testing and Materials (ASTM) standard exists for consolidated undrained triaxial extension testing for cohesive soils, the triaxial apparatus was assembled following the procedures outlined in Section 7 of ASTM D 4767 (2004) during both series of experiments. The wet mounting method (Section 7.2.1) was employed and filter-paper disks and a filter-paper cage were used. The filter-paper cage consisted of angled strips (48 degrees from horizontal) with a side surface coverage area of 58 percent to reduce hoop stress and axial load while enabling horizontal drainage. The membrane used was a latex, non-lubricated condom with the end cut. The membrane was connected to the top and 
bottom caps of the sample using rubber O-rings. New filter paper disks, filter paper cages, and membranes were used for each test.

\section{Testing Equipment}

Trautwein GEOTAC equipment was used to conduct this research. The equipment used includes: a 5-kip (22 kN) Sigma-1 automated load frame, a $155 \mathrm{ml}$ DigiFlow automated flow pump (300 psi [2069 kPa] maximum pressure output), a $75 \mathrm{ml}$ DigiFlow automated flow pump (300 psi [2069 kPa] maximum pressure output), a 5-inch $(12.7 \mathrm{~cm})$ diameter triaxial cell (with vacuum top cap connection port and internal load cell connection port), a $200 \mathrm{psi}(1378 \mathrm{kPa}$ ) pore pressure transducer, a 100 pound (444 N) external load cell, a 100 pound (444 N) internal load cell and a 1.5 inch stroke direct current displacement transducer. $\quad$ Trautwein GEOTAC Truepath-SI, Version 1.0.1 software was used to control the testing equipment and to collect data.

\section{Experiments Conducted Using Brass Dummy Sample}

For experiments conducted using a brass dummy sample, a brass dummy sample was inserted into the triaxial apparatus in the place of a soil sample to isolate the piston uplift and piston friction components of the axial load. The brass sample served as a place holder while saturating the specimen drainage lines and the pore-water pressure measurement device with deaired water and while varying the cell pressure and pore-water pressure.

For experiments conducted using the brass dummy sample, three connections types were utilized to connect the specimen top cap with the external load cell. The specimen top cap connections include: a rigid connection without an internal load cell, a rigid connection with an internal load cell, and a vacuum connection with an internal load cell. Photographs and schematics of the three connection types are presented in Figures 1 and 2.

The rigid connection without the internal load cell (Figures 1a and 2a) is attached to the sample by screwing the piston rod into the sample top cap without torquing the sample. After attaching the piston rod to the sample top cap and before filling the cell, the piston is locked in place using the piston lock. The external load cell is then screwed onto the piston (then the electronic cable is attached to the load cell) and the triaxial cell is attached to the load frame base platen using C-clamps. The piston is attached to the load frame by lowering the load frame reaction bar until it rests on the nut between the load frame reaction bar and the external load cell and then screwing the load frame connection bolt into the load cell. The connection bolt and load frame reaction bar are repositioned until no load is registered in the external load cell.

The rigid connection including an internal load cell (Figures $1 \mathrm{~b}$ and $2 \mathrm{~b}$ ) is attached to the sample by screwing a 2.0 inch $(5.08 \mathrm{~cm})$ long piece of piston rod (referred to as a union) into the sample top cap without torquing the sample. The internal load cell is then screwed onto the union and the cell wall is placed around the sample. The internal load cell electronics are then attached to the triaxial cell top cap electronics and the triaxial cell top cap is lowered onto the cell wall with the piston unlocked. After the triaxial cell top cap is attached to the cell wall, the piston is screwed into the internal load cell (without torquing the sample) then locked using the piston lock. After the piston is locked, the procedure for connecting the triaxial cell to the load frame is the same as for the rigid connection. 
The vacuum connection, including an internal load cell (Figure 1c and 2c), is attached to the sample by screwing the piston into the load cell attached to the top half of the sample top cap and then connecting the top half of the sample top cap to the bottom half of the sample top cap using a vacuum connection (the vacuum line runs through the top cap of the triaxial cell). After the vacuum connection is established, the piston is locked and the procedure for connecting the triaxial cell to the load frame is the same as for the rigid connection

After the triaxial cell was assembled and connected to the load frame, tests were conducted by varying the cell pressure, pore pressure and confining pressure, and measuring the load response in the axial load cell(s). The various pressure combinations used for these experiments are listed in Table 1.

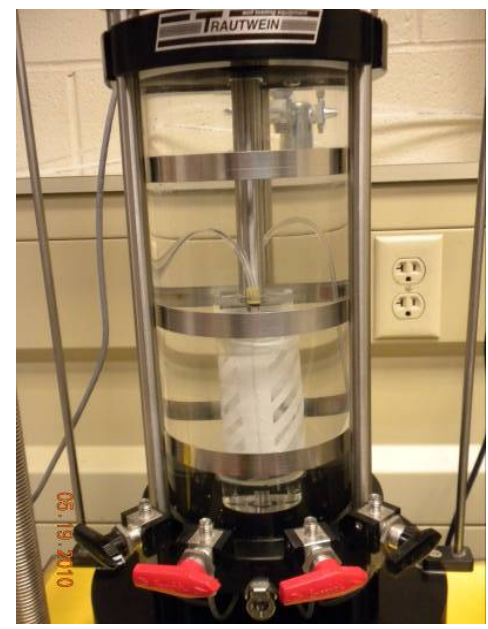

(a)

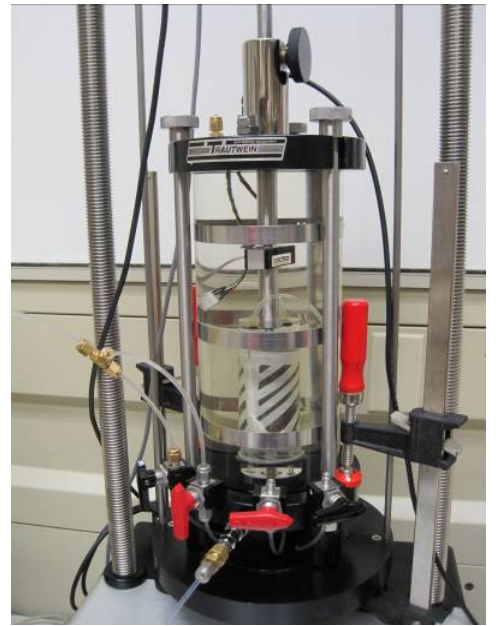

(b)

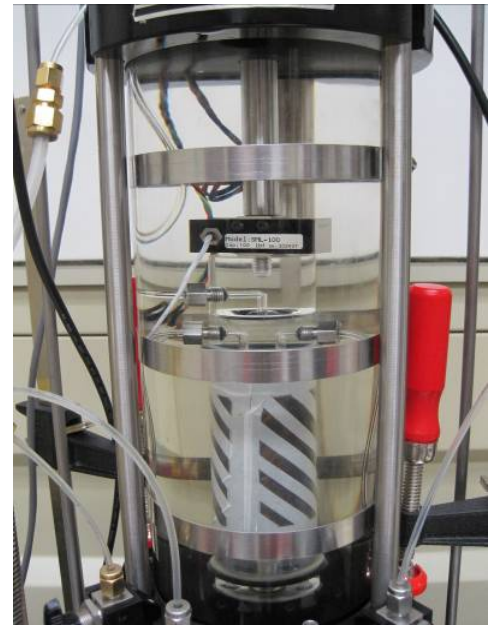

(c)

Figure 1. (a) Photograph of rigid connection between piston applying axial load and sample top cap (without an internal load cell), (b) photograph of rigid connection between piston applying axial load and sample top cap (with an internal load cell), and (c) photograph of vacuum connection between piston applying axial load and sample top cap (with an internal load cell). 


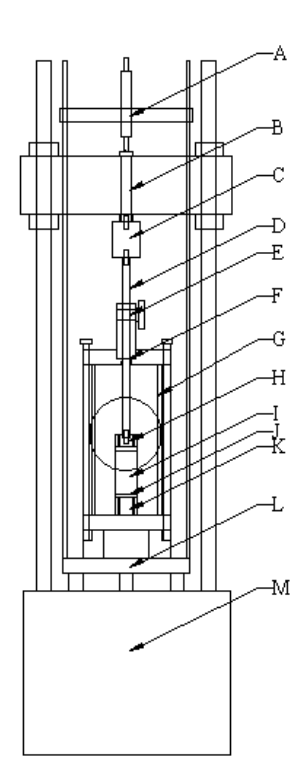

(a)

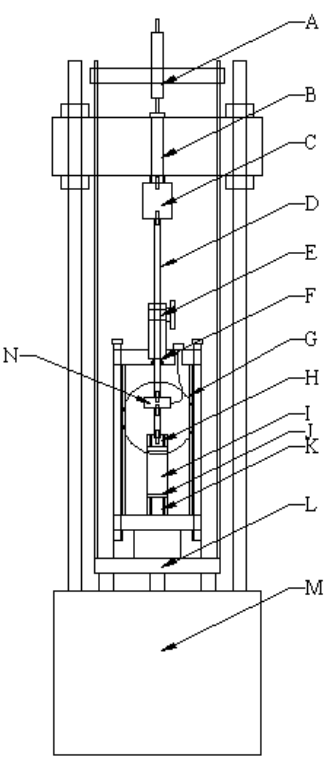

(b)

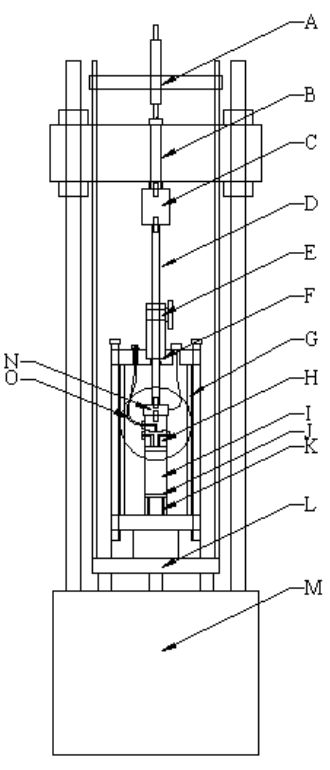

(c)
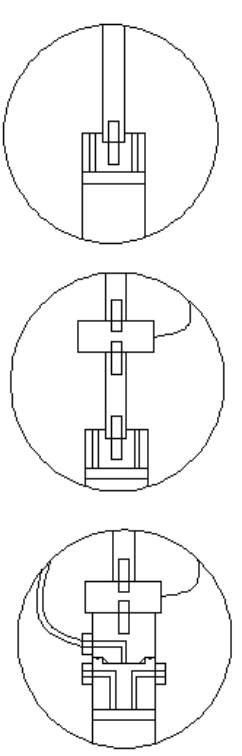
A. DCDT
B. Load Frame Connection
C. External Load Cell
D. Piston

F. Bushing Housing

G. Cell Wall

H. Sample Top Cap

I. Sample

J. Porous Stone

K. Sample Base Cap

L. Load Frame Base Platen

M. Load Frame Motor

N. Internal Load Cell

O. Vacuum Line

Figure 2. (a) Schematic of rigid connection without internal load cell, (b) schematic of rigid connection with internal load cell, and (c) schematic of vacuum connection with internal load cell.

Table 1. Combinations of cell pressure, pore pressure and confining pressure.

\begin{tabular}{|c|c|c|c|c|c|c|c|c|c|c|c|c|c|c|c|c|c|c|}
\hline \begin{tabular}{|l|} 
Effective \\
Confining
\end{tabular} & \multicolumn{18}{|c|}{$\begin{array}{l}\text { Cell Pressure (psi) } \\
\text { Pore Pressure (psi) }\end{array}$} \\
\hline \multirow{4}{*}{5} & 6 & 11 & 16 & 21 & 26 & 31 & 36 & 41 & 46 & 51 & 56 & 61 & 66 & 71 & 76 & 81 & 86 & 91 \\
\hline & 1 & 6 & 11 & 16 & 21 & 26 & 31 & 36 & 41 & 46 & 51 & 56 & 61 & 66 & 71 & 76 & 81 & 86 \\
\hline & 96 & 101 & 106 & 111 & 116 & 121 & 126 & 131 & 136 & 141 & 146 & & & & & & & \\
\hline & 91 & 96 & 101 & 106 & 111 & 116 & 121 & 126 & 131 & 136 & 141 & & & & & & & \\
\hline \multirow{4}{*}{10} & 11 & 16 & 21 & 26 & 31 & 36 & 41 & 46 & 51 & 56 & 61 & 66 & 71 & 76 & 81 & 91 & 96 & 101 \\
\hline & 1 & 6 & 11 & 16 & 21 & 26 & 31 & 36 & 41 & 46 & 51 & 56 & 61 & 66 & 71 & 81 & 86 & 91 \\
\hline & 106 & 111 & 116 & 121 & 126 & 131 & 136 & 141 & 146 & & & & & & & & & \\
\hline & 96 & 101 & 106 & 111 & 116 & 121 & 126 & 131 & 136 & & & & & & & & & \\
\hline \multirow{4}{*}{20} & 21 & 26 & 31 & 36 & 41 & 46 & 51 & 56 & 61 & 66 & 71 & 76 & 81 & 86 & 91 & 96 & 101 & 106 \\
\hline & 1 & 6 & 11 & 16 & 21 & 26 & 31 & 36 & 41 & 46 & 51 & 56 & 61 & 66 & 71 & 76 & 81 & 86 \\
\hline & 111 & 116 & 121 & 126 & 131 & 136 & 141 & 146 & & & & & & & & & & \\
\hline & 91 & 96 & 101 & 106 & 111 & 116 & 121 & 126 & & & & & & & & & & \\
\hline \multirow{4}{*}{40} & 41 & 46 & 51 & 56 & 61 & 66 & 71 & 76 & 81 & 86 & 91 & 96 & 101 & 106 & 111 & 116 & 121 & 126 \\
\hline & 1 & 6 & 11 & 16 & 21 & 26 & 31 & 36 & 41 & 46 & 51 & 56 & 61 & 66 & 71 & 76 & 81 & 86 \\
\hline & 131 & 136 & 141 & 146 & & & & & & & & & & & & & & \\
\hline & 91 & 96 & 101 & 106 & & & & & & & & & & & & & & \\
\hline \multirow{2}{*}{60} & 61 & 66 & 71 & 76 & 81 & 86 & 91 & 96 & 101 & 106 & 111 & 116 & 121 & 126 & 131 & 136 & 141 & 146 \\
\hline & 1 & 6 & 11 & 16 & 21 & 26 & 31 & 36 & 41 & 46 & 51 & 56 & 61 & 66 & 71 & 76 & 81 & 86 \\
\hline \multirow{2}{*}{80} & 81 & 86 & 91 & 96 & 101 & 106 & 111 & 116 & 121 & 126 & 131 & 136 & 141 & 146 & & & & \\
\hline & 1 & 6 & 11 & 16 & 21 & 26 & 31 & 36 & 41 & 46 & 51 & 56 & 61 & 66 & & & & \\
\hline
\end{tabular}




\section{Experiments Conducted Using Ice Dummy Sample}

Ice samples were inserted into the triaxial apparatus in the place of a soil sample to isolate the membrane elongation and filter paper components of the axial load. The ice samples were prepared by freezing deaired water in a 1.5-inch $(3.81 \mathrm{~cm})$ diameter by 3.0 inch $(7.62 \mathrm{~cm})$ tall mold made from Schedule 40 PVC (Figure 3a). Due to expansion of water during freezing, the samples were trimmed to 3.0 inches $(7.62 \mathrm{~cm})$ in length prior to extracting the ice sample (Figure $3 \mathrm{~b}$ ). The ice sample served as a place holder while saturating the specimen drainage lines and the pore-water pressure measurement device with deaired water.

After assembling the triaxial apparatus and saturating the specimen drainage lines and pore-water measurement device with deaired water, the piston was locked in place and the ice sample was allowed to melt. A waiting period of 24 hours was utilized to ensure the ice sample was completely melted before the shearing stage was begun.

The melted ice (water) samples were sheared in extension at a strain rate of 0.5 percent per hour using different confining pressures. Tests were conducted at different confining pressures to determine if the variation in confining pressure affects the membrane elongation and filter paper components of the axial load. The confining pressures used include: 0 psi (0 kPa), 30 psi (207 kPa), 60 psi (414 kPa), 90 psi (621 kPa), 120 psi (827 kPa), 150 psi (1034 kPa). All tests were conducted with an effective confining pressure of $0 \mathrm{psi}(0 \mathrm{kPa})$ by using the same pump to control the pore-water pressure and the cell water pressure.

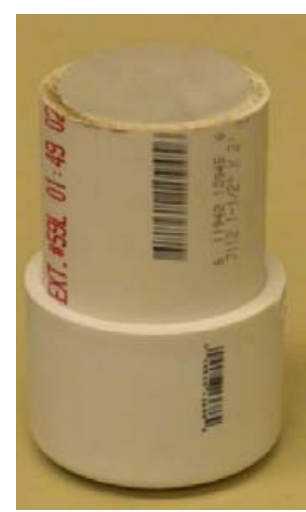

(a)

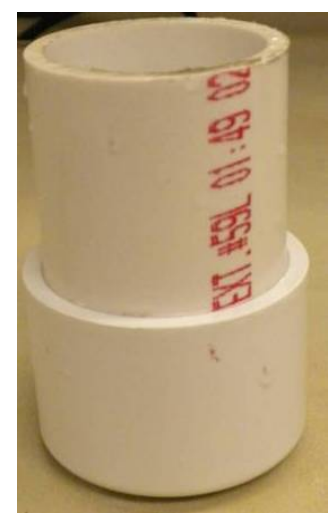

(b)

Figure 3. (a) Photograph of mold used to make ice samples with ice sample prior to shaping ice sample, (b) photograph of mold used to make ice samples with ice sample after shaping ice sample prior to ice sample extraction.

The rigid connection without an internal load cell was used to connect the specimen top cap with the external load cell. This connection was selected because of the ease of setup and the limitations of many labs not having cells with internal load cell capability. Ongoing research at the University of Arkansas is focusing on using the other connection types (rigid with internal load cell, vacuum with internal load cell) but the results from this research were not available for this publication. 


\section{RESULTS}

A series of 21 tests were conducted to measure the uplift and piston friction components of the axial load and to measure membrane elongation and filter paper components of the axial load. Ten (10) tests were conducted on a brass dummy sample to isolate the uplift and piston friction components of axial load while eleven (11) test were conducted on dummy ice samples to isolate the membrane elongation and filter paper components of axial load. The results from the series of tests are discussed.

\section{Uplift and Piston Friction}

The recommended downward force required to counteract the uplift force caused by the cell pressure ejecting the piston is presented in Equation 2 (Trautwein, 2010).

$$
\text { DF }=\sigma_{c} A_{\text {psiton }} \quad \text { Equation } 2
$$

With DF representing the downward force recorded in the external load cell (in lb or N), $\sigma_{c}$ representing the total confining stress (in psi or $\mathrm{Pa}$ ) and $\mathrm{A}_{\text {piston }}$ representing the crosssectional area of the piston (in $\mathrm{in}^{2}$ or $\mathrm{m}^{2}$ ). This recommended downward force is the same regardless if the sample is being sheared in extension or compression and is plotted as the "recommended downward force" in Figure 4. At effective stresses larger than 5 psi, the recommended downward force plots below the measured uplift force (including piston friction) for each cell pressure. Thus, using the recommended downward force equation will cause the vertical stress to be less than what is required for consolidation and shear. This reduction in stress will result in a sample that is not correctly isotropically or anisotropically consolidated (the axial stress is less than required). Therefore, it is recommended that the required downward force be calculated using the trendline (excluding the 5 psi data) through the measured data (as presented in Equation 3).

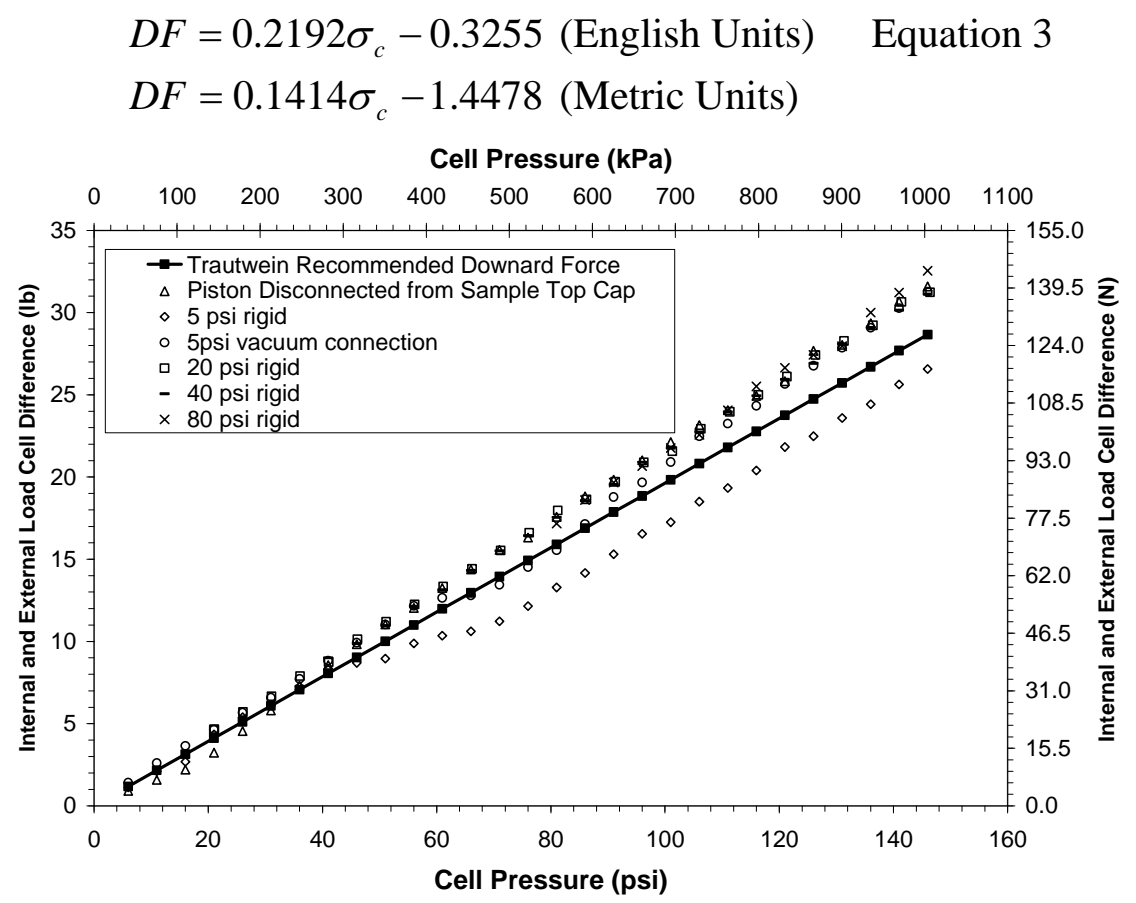

Figure 4. Recommended downward force and measured upward force. 
Typically, during consolidated undrained triaxial testing, the sample is backpressure saturated under a low confining stress $(5 \mathrm{psi})$ by increasing the back pressure and pore pressure simultaneously until the B-value indicates the sample is saturated. Because the piston is connected to the sample during triaxial extension testing, the downward force must counterbalance the upward force being exerted by the cell pressure on the piston.

When using low confining stresses (between a cell pressure of $0 \mathrm{psi}[0 \mathrm{kPa}]$ and approximately $46 \mathrm{psi}$ [317 $\mathrm{kPa}]$ ), the downward force exerted on the piston by the connection with the sample top cap is initially larger than the upward force exerted on the piston by the cell pressure. As the cell pressure increases (approximately $46 \mathrm{psi}$ [317 kPa] to $150 \mathrm{psi}[1034 \mathrm{kPa}]$ ) the downward force becomes an upward force resulting in a change in the external load cell from tension to compression (Figure 5). This change in the external load cell causes non-unique hysteresis in the axial load-cell pressure curve. Because this hysteresis is non unique, it is recommended that samples are back pressure saturated using effective stresses larger than $10 \mathrm{psi}(69 \mathrm{kPa})$ for triaxial extension testing, enabling proper downward force to be applied without hysteresis.

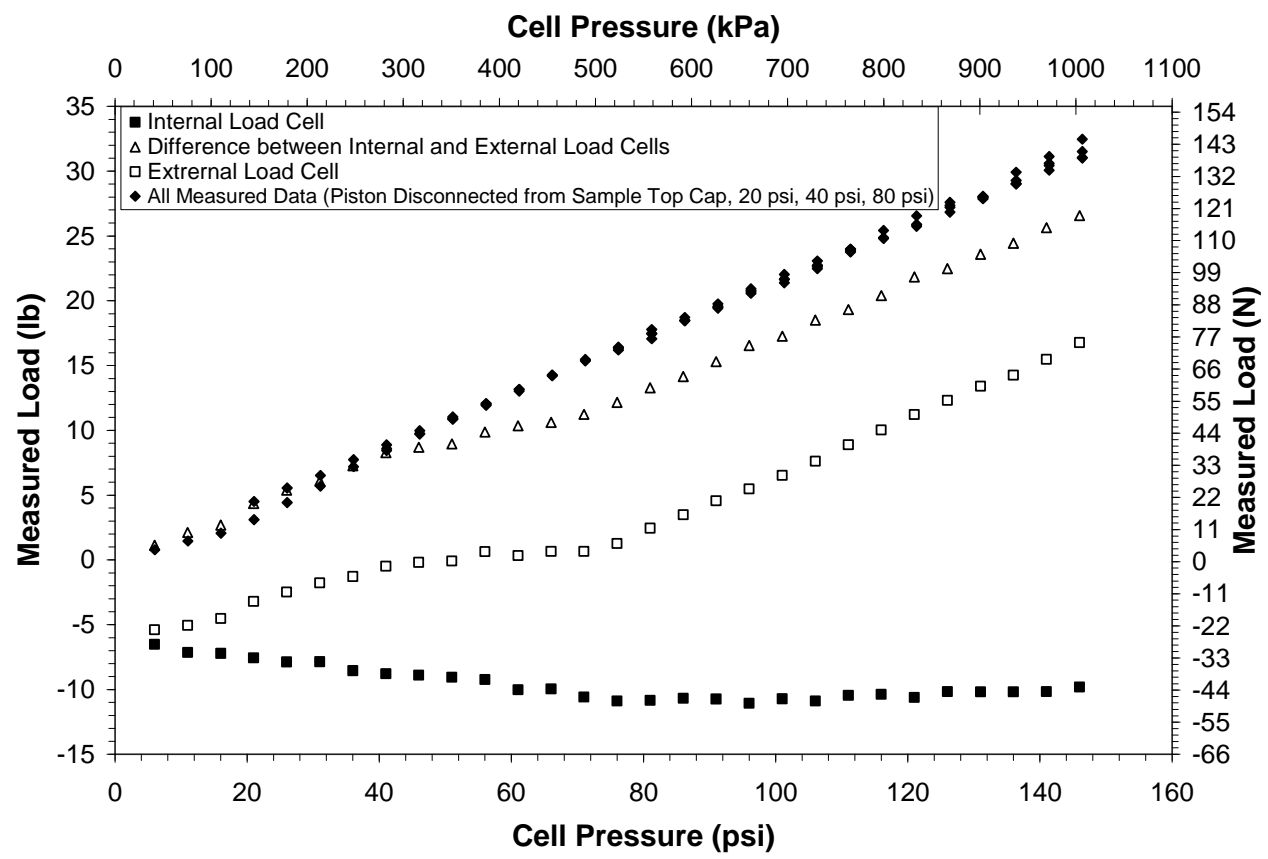

Figure 5. Hysteresis in measured load while using low effective confining stress during back pressure saturation.

\section{Membrane Elongation and Filter Paper}

Unlike triaxial compression testing in which the membrane and filter paper cage are in compression, during triaxial extension testing the membrane and filter paper cage are in tension. Because the membrane and filter paper cage are in tension, and are significantly contributing to the measured axial load, the components of the axial load caused by membrane elongation and filter paper must be subtracted from the measured load to obtain the correct shear strength. Eleven tests on water samples were conducted to determine the contribution of membrane elongation and filter to the axial load. Because water has no shear strength, the measured load is the membrane elongation and filter paper contribution 
to the axial load. Normalized (measured load divided by total cell pressure) results are presented in Figure 6 for five (5) tests conducted with different total cell pressure values. For strains less than four percent, the normalized behavior is dependent on total cell pressure, with lower cell pressures displaying lower normalized load. For stains larger than four percent, the normalized behavior of the samples with confining pressures larger than $60 \mathrm{psi}(267 \mathrm{kPa}$ ) appears to be constant. Because the normalized curves are different below 4 percent, it is recommended that a normalized curve be obtained (using a dummy ice/water sample) based on the total cell pressure used for the test on soil and subtracted from the measured soil curve for each test conducted. The curves presented in Figure 6 were obtained without an effective stress being applied to the sample (equal pore water pressure and cell water pressure). The contribution of the membrane elongation and filter paper to the measured axial load on soil samples will be larger than the measured axial load on water samples because water is unable to sustain an effective stress. This additional contribution cannot be accounted for using the previously described procedures.

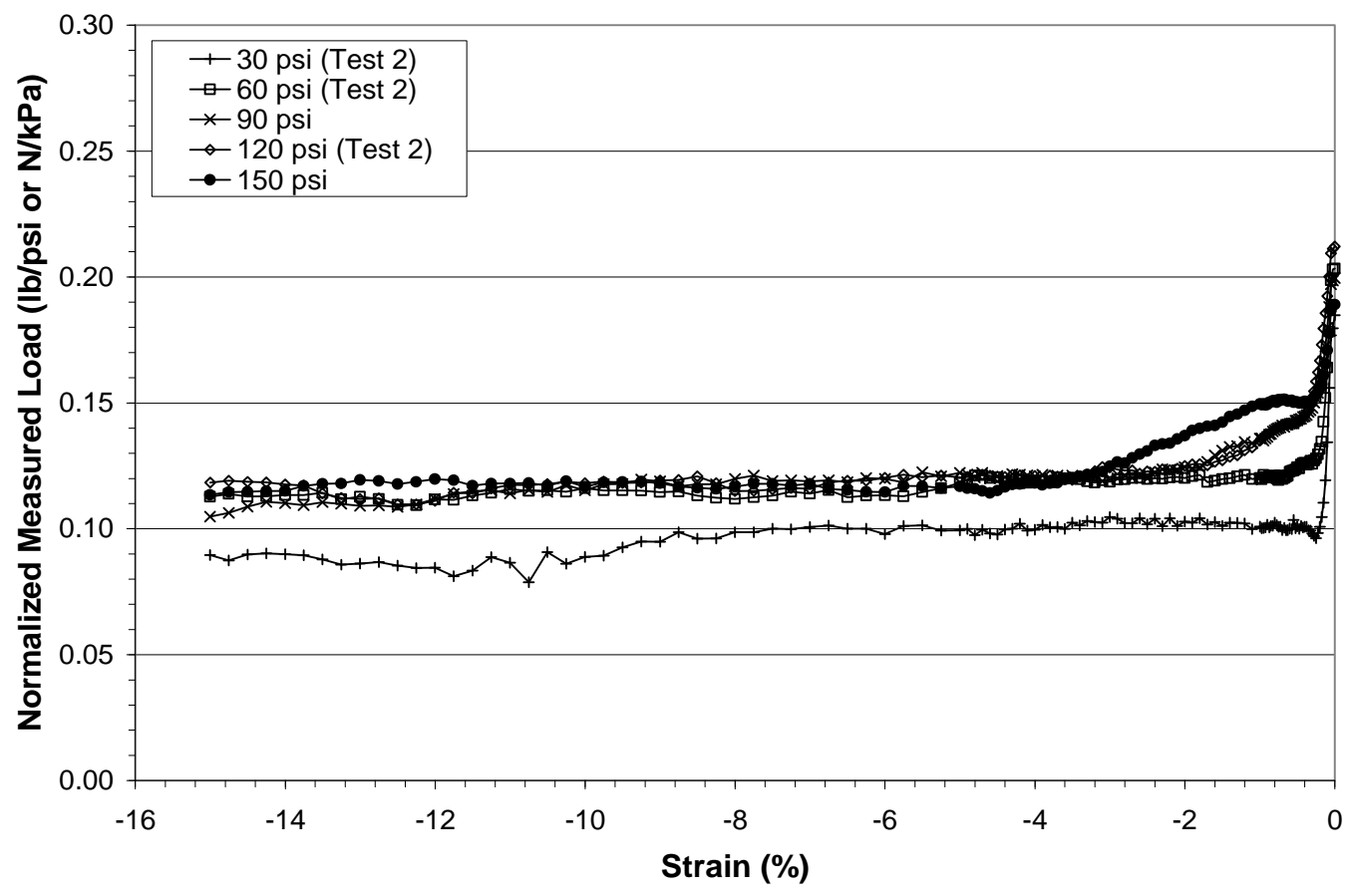

Figure 6. Apparent shear strength measured on membrane and filter paper encompassed water samples.

\section{CONCLUSIONS}

Unlike triaxial compression tests in which the sample can be consolidated without the piston being in contact with the sample top cap, triaxial extension tests require the piston to be connected to the sample top cap during consolidation. Also, unlike triaxial compression tests in which the membrane and filter paper provide a negligible contribution to the measured load, these components provide a significant contribution in triaxial extension testing. Piston uplift, piston friction, membrane elongation, and filter paper effects must be accounted for and subtracted from the measured load to ensure the correct stress is applied to the sample and the correct shear strength is measured. Effective 
confining stresses larger than 5 psi are suggested for use during back pressure saturation to prevent non-unique load hysteresis.

\section{REFERENCES CITED}

American Society for Testing and Materials (2004), "Standard Test Method for Consolidated-Undrained Triaxial Compression Test for Cohesive Soils” Annual Book of ASTM Standards, Designation D 4767, Vol. 4.09, ASTM, West Conshohocken, PA.

Bishop, A.W., and Henkel, D.J. (1962). "The Measurement of Soil Properties in the Triaxial Test.” Edward Arnold LTD, London.

Donaghe, R.T., and Townsend, F.C. (1978). "Effects of Anisotropic Consolidation in Consolidated-Undrained Triaxial Compression Tests of Cohesive Soils.” ASTM Geotechnical Testing Journal, Vol. 1, No. 4, Dec., pp. 173-189.

Ladd, C.C. and DeGroot, D. J. (2003). "Recommended Practice for Soft Ground Site Characterization: Arthur Casagrande Lecture.” $12^{\text {th }}$ Panamerican Conference on Soil Mechanics and Geotechnical Engineering. Massachusetts Institute of Technology, Cambridge, MA, June 22-25, 2003, 55 pp.

Ladd, C.C, and Foott, R., (1974) "New Design Procedure for Stability of Soft Clays," Journal of Geotechnical Engineering Division, Vol.100, No. GT7, July.

Lade, P.V., Yamamuro, J.A., Skeyrs, B.D. (1996) "Effects of Shear Band Formation in Triaxial Extension Tests” ASTM Geotechnical Testing Journal, Vol. 19, No. 4, Dec., pp. 398-410.

Mitachi, T., Kohata, Y., Kudoh Y., "The Influence of Filter Strip Shape on Consolidated Undrained Triaxial Extension Test Results” Advanced Triaxial Testing of Soil and Rock, ASTM STP 977, Robert T. Donaghe, Ronald C. Chaney, and Marshall L. Silver, Eds., American Society for Testing and Materials, Philadelphia, 1988. pp. 667-678.

Parry, R.H.G. (1960). "Triaxial Compression and Extension Tests on Remolded Saturated Clay.” Geotechnique, Vol. 10, No. 4, pp. 166-180.

Trautwein, Steven, (2010). Personal Communication.

Wu, W., Kolymbas, D. (1991) “On Some Issues in Triaxial Extension Tests” ASTM Geotechnical Testing Journal, Vol. 14, No. 3, Sept., pp. 276-287.

Yamamuro, J.A., Lade, P.V., (1995) "Strain Localization in Extension Tests on Granular Materials” Journal of Engineering Mechanics Vol. 121, No.7, pp. 828-836. 